Neurological symptoms could arise from defects in $X P / E R C C / C S$ genes in at least two ways. Unrepaired DNA damage might be particularly deleterious to critical gene expression in nervous tissue and lead to progressive neurological deterioration ${ }^{24}$. Alternatively, developmental abnormalities might arise if an $E R C C / X P / C S$ gene product functioned in both DNA repair and gene expression. This may indeed be the case for $E R C C 3 / X P B C / C S-C$ (refs 25,26 ).

Two XP groups remain for which genes have not been assigned (XP-E and XP-F), and any relationship between these and the set of ultraviolet-sensitive rodent complementation groups could be investigated by a similar approach. In this way a more complete picture can be drawn of the activities and genes involved in nucleotide excision repair which will facilitate mechanistic dissection of the process.

Received 30 December 1992; accepted 8 March 1993.

1. Keijzer, W. et al. Mutat. Res. 62, 183-190 (1979)

2. Arlett, C. F. et al. Carcinogenesis 1, 745-751 (1980).

3. Ichihashi, M., Fujiwara, Y., Uehara, Y. \& Matsumoto, A. J. Invest. Dermat. 85, 284-287 (1985). 4. Norris, P. G., Hawk, J. L. M., Avery, J. A. \& Giannelli, F. Brit. J. Dermat. 116, 861-866 (1987).

5. Vermeulen, W., Osseweijer, P., de Jonge, A. J. R. \& Hoeijmakers, J. H. J. Mutation Res. 165, 199-206 (1986).

6. Yamaizumi, M., Sugano, T., Asahina, H., Okada, Y. \& Uchida, T. Proc. natn. Acad. Sci. U.S.A. 83, $1476-1479$ (1986).

7. Wood, R. D., Robins, P. \& Lindahl, T. Cell 53, 97-106 (1988)

8. Hansson, J., Grossman, L., Lindahl, T. \& Wood, R. D. Nucleic Acids Res. 18, 35-40 (1990).

9. Biggerstaff, M. \& Wood, R. D. J. biol. Chem. 267, 6879-6885 (1992).

10. Busch, D. et al. Mutagenesis 4, 349-354 (1989).

11. Riboni, R., Botta, E., Stefanini, M. Numata, M. \& Yasui, A. Cancer Res. 52, 6690-6691 (1992).

12. Flejter, W. L., McDaniel, L. D., Johns, D. Friedberg, E. C. \& Schultz, R. A. Proc natn. Acad. Scj. U.S.A. 89, 261-265 (1992).

13. Weeda, G. et al. Cell $62,777-791(1990)$

14. Mudgett, J. S. \& Maclnnes, M. A. Genomics 8, 623-633 (1990).

15. Barbis, D. P., Schultz, R. A. \& Friedberg, E. C. Mutation Res. 165, 175-184 (1986).

16. Klein, B., Pastink, A., Odijk, H., Westerveld, A. \& van der Eb, A. J. Expl Cell Res. 191, 256-262 (1990). 17. Scherly, D. et al. Nature 363, 182-185 (1993).

18. Thompson, L. H. et al, Somat. Cell molec. Genet. 13, 539-551 (1987).

19. Warburton, D., Yu, M.-T., Richardson, C., Mudgett, J. S. \& Macinnes, M. A. Cytogenet. Cell Genet. 58, 1984 (1991)

20. Takahashi, E., Shiomi, N. \& Shiomi, T. Jpn J. Cancer Res. 83, 1117-1119 (1992).

21. Troelstra, C. et al. Cell 71, 939-953 (1992).

22. Robbins, J. H. Hum. Genet. 88, 242 (1991).

23. Jaeken, J. et al. Hum. Genet. 83, 339-346 (1989).

24. Andrews, A. D., Barrett, S. F. \& Robbins, J. H. Proc. natn. Acad. Sci. U.S.A. 75, 1984-1988 (1978) 25. Gulyas, K. \& Donahue, T. Cell 69, 1031-1042 (1992)

26. Mounkes, L. C., Jones, R. S., Liang, B.-C., Gelbart, W. \& Fuller, M. T. Cell 71, 925-937 (1992).

27. Robins, P., Jones, C. J., Biggerstaff, M., Lindahl, T. \& Wood, R. D. EMBO J. 10, 3913-3921 (1991) 28. Wood, R. \& Burki, H. J. Mutation Res. 95, 505-514 (1992).

ACKNOWLEDGEMENTS. We thank J. Cole for blood samples; our colleagues who supplied cell lines from their collections; the ICRF Cell Production Unit for assistance; members of our laboratory for reagents and for discussion; and S. Clarkson, D. Scherly and their colleagues for discussion, advice and for antibodies.
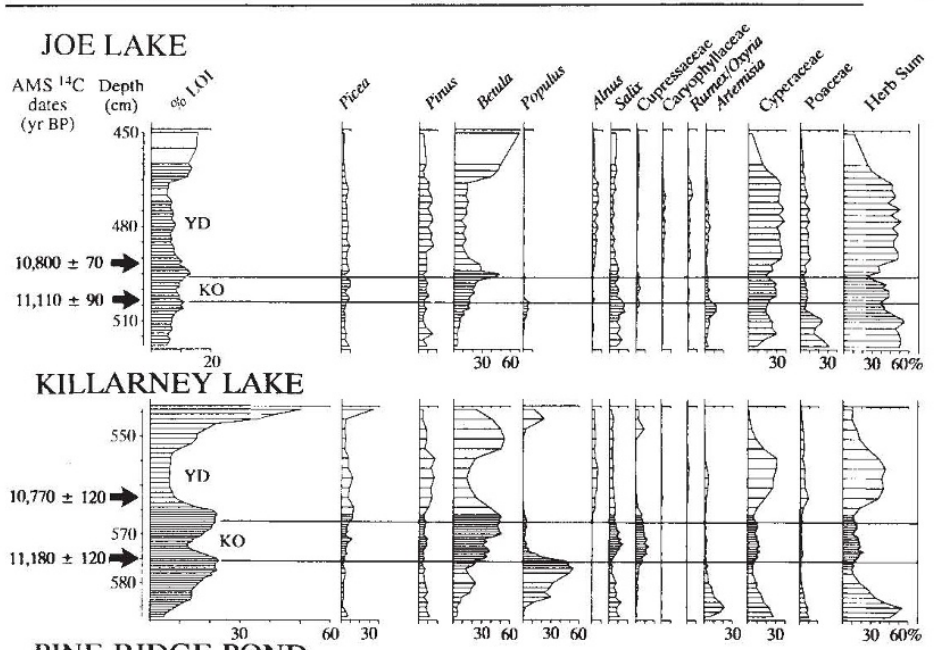

PINE RIDGE POND

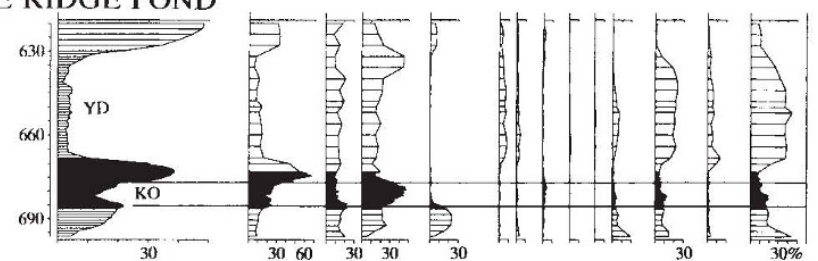

CORRECTION

\section{Flightless bird from the Cretaceous of Mongolia}

\author{
Perle Altangerel, Mark A. Norell, Luis M. Chiappe \\ \& James M. Clark
}

Nature 362, 623-628 (1993)

IT has been brought to our attention by Ben Creisler that the genus name Mononychus used to refer to a new flightless Cretaceous bird in our letter to Nature is preoccupied by the coleopteran Mononychus Schueppel 1824 (ref. 1). We therefore propose the replacement Mononykus for this genus whose type species is Mononykus olecranus.

1. Schueppel, J. F. in Insectorum species novae aut minus cognitae, descriptionibus illustratae Vol. 1 Coleoptera (ed. Germar, E. F.) (Halle, 1824).

\section{ERRATUM}

\section{A previously unrecognized late-glacial cold event in eastern North America}

\section{André J. Levesque, Francis E. Mayle, lan R. Walker \& Les C. Cwynar}

Nature 361, 623-626 (1993)

IN the printed version of Fig. 2 in this letter, several of the ${ }^{14} \mathrm{C}$ dates shown by arrows were omitted. The correct version is shown below, together with the legend.

FIG. 2 Pollen percentage diagrams from six sites in Maritime Canada. The thick continuous horizontal lines indicate the boundaries of the KO based on the LOI curves, as discussed in the text. YD, Younger Dryas. Each horizontal line of the LOI and pollen curves represents one sample.

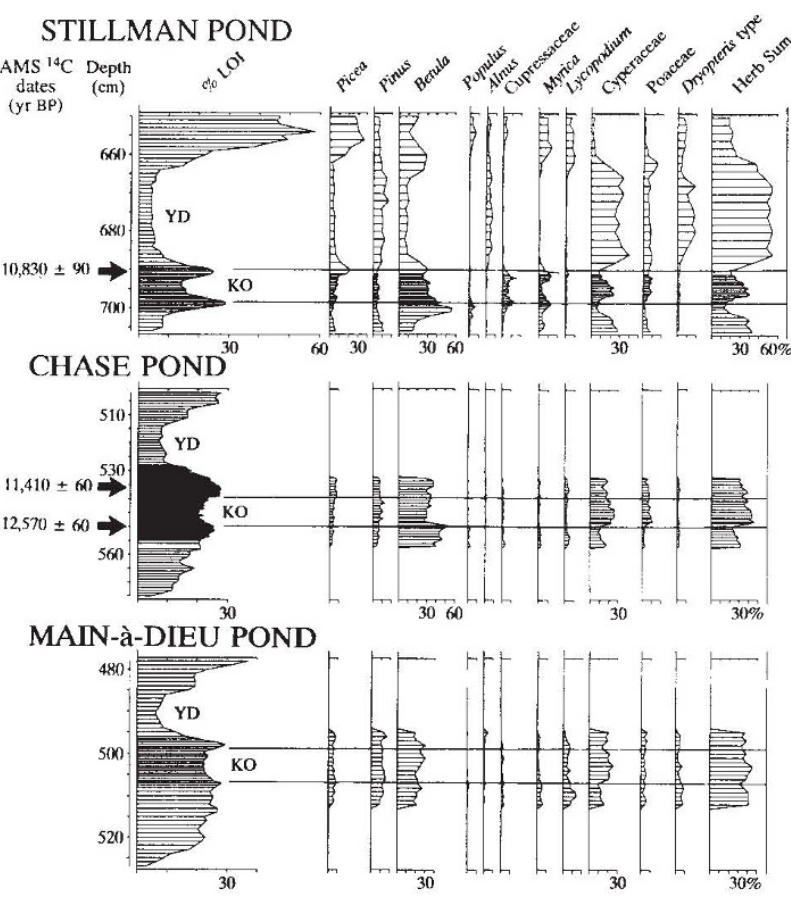

